\title{
5 \\ The PLA, the CCP and the formulation of Chinese defence and foreign policy
}

\section{You Ji}

In 1997, the People's Liberation Army (PLA) celebrated its 70th birthday. Without the PLA, the People's Republic of China (PRC), which just marked its fiftieth anniversary, would not exist. Looking back, a lot of changes have taken place in both the PLA and the PRC. How can we summarise these changes in the PLA and its relations with the Chinese Communist Party (CCP), and its child, the PRC? This chapter describes this evolutionary process in the following characterisation: from protecting revolution to serving national interests. In a way, this 50-year process of evolution has seen a profound transition in the PLA. In its relations with the Party, the PLA has slowly moved beyond symbiosis. In its modernisation, the PLA has changed from being a semirevolutionary, semi-professional army into a true professional military. In terms of its overriding functions, it is gradually shifting its emphasis from domestic politics to external missions. This has inevitably re-shaped its behaviour in the foreign policy arena, and these changes will accelerate and become more visible as China moves into the post-jiang era. 


\section{A new balance of power between civilian and military leaders}

In modern societies there are two types of civil/military relations. In democracies, the military is under objective control based on the foundation of two pillars. First, objective control promotes professionalism as a distinct value judgment in the military. Professionalism regulates soldiers' political ambitions and purifies their behaviour. Second, objective control promotes an institutionalised process to restrict the actions of generals to within a legitimate range. Under objective control, the armed forces have a simple function-guarding the nation against external threat.' This liberal model makes the military more a client of the state than a tool of a political party or leader.

In contrast, armed forces in authoritarian countries have a much wider range of missions. There, the emergence of independent nationhood parallels the rise of military power. The soldiers are motivated by revolutionary ambitions which are fuelled by ideological ferment and nationalist frenzy brought about by colonial suppression. This fosters a strong tendency for military intervention in domestic politics, because the military tries to ensure the nation is following the appropriate political course. Often the generals are under a different kind of civilian control-the subjective control under which the military displays its loyalty to one particular political leader. Revolutionary goals, political/ideological preferences and national interests become blurred in the minds of generals who see their duties as ranging from domestic politics to international pursuits. $^{2}$

China's civil/military relations fall largely in the second category, largely because of historical factors. The Party founded the army and established effective control mechanisms within it to ensure that soldiers stayed loyal to the CCP and the revolution. The PLA has not disappointed the Party in this regard. During the 28 years of armed struggle for survival and national power, the CCP and PLA fought side by side, forging a symbiotic relationship-the demise of one would signal the demise of the other. ${ }^{3}$ The PLA has 
come to the rescue of the Party several times since the founding of the PRC, the latest occasion being the clampdown of the Tiananmen rebellion in 1989, which drew a sharp contrast with the Red Army in the USSR in 1991.

On the other hand, there have been clear signs that this symbiotic relationship is losing its power on both sides. After all, survival was no longer a pressing issue once the PRC came into being. As the new state consolidated and adapted to a peaceful environment, the soldiers' revolutionary zeal was gradually replaced by professional concerns. The civil-military relations characterised as war-time symbiosis underwent qualitative change and are now centred around shared interests. In peacetime, the closeness of CCP-PLA relations is based on a common interest in preserving their privileged position in the nation's politics. This may provide the basis for long-standing partnership. Eventually, however, the military may decide that protecting a deeply corrupt political party is a liability in protecting its own interests and adopt a more independent position. This process of divorce between the civilian and military authorities happened in almost all Chinese dynasties in their last days. It has also happened in most transforming communist societies. The likely outcome of this development would see the military surviving the decay of the Party and remaining the most important institution of power in the new political system. Taiwan's recent experience has demonstrated the possibility of this development on the mainland. In Taiwan, the Nationalist military (Guojun) continues to serve the new government as a key political player while its founder has lost power. ${ }^{4}$

Yet the PLA is no longer the only key interest group in the political system, even though it remains the most powerful one. Other power groups have emerged and become entrenched. For instance, the state bureaucracy now wields enormous power in state affairs. Under this new power structure, the PLA's corporate identity is highlighted rather than reduced. With irreplaceable functions to perform in society, the space for the PLA to improve its professionalism is constantly growing. Today, modernisation and regularisation have become the primary concern of the officers and soldiers, although this is still decorated in the rhetoric of 
revolution. The PLA has never before been driven so strongly by the same forces as Western militaries - the ideal of professionalism, defined by 'expertise, responsibility and corporateness'. What exactly has actually happened in CCP-PLA relations during the fifty year life of the PRC? Comparison of different eras is the best indicator.

\section{Transition from strongman control to institutionalised leadership}

One clear indication of the PLA's deepening professionalisation has been the disappearance of personal control by the strongmen. The historical legacy of the CCP and the PLA meant that the military came under personal control in the Mao and Deng eras. The object of loyalty of the armed forces was not the nation, the state or even the Party, but one particular individual. Personal control is a particular type of civil-military relations in which one political leader is able to impose his own preferences on the military without consultation with the high command. In China, this resulted in the bitter lessons of the Cultural Revolution when Mao forced factional politics into the PLA. ${ }^{5}$ Indeed, when politics enters the military, the military becomes politicised and fragmented, which gravely undermines national security.

Deng Xiaoping believed that personal control may be a necessary evil when an overriding authority is needed to push through controversial reforms. This can best be seen from his incitement to Yang Baibing in 1992 to raise a slogan of 'baojia huhang' (meaning that the PLA had a mission to protect Deng's reforms), in order to intimidate the first line party leaders who were thought to deviate from Deng's political line. This was the most serious military interference in Chinese domestic politics in the reform era, and in a way was not that different to when Mao drew the PLA into party factional infighting in $1966 .^{\circ}$

Deng, however, also realised the danger of this personal control to the nation's political stability and the PLA's professionalisation. He was keenly aware that he was the only person left in the Party 


\section{The formulation of Chinese defence and foreign policy}

capable of exercising personal control over the PLA. He realised that there would be a vacuum of civilian control over the military after his death unless measures were taken while he was still alive. He saw personal control as an unhealthy form of civil-military relations that had to be eliminated. Consciously or unconsciously, he actually campaigned for a kind of objective control in his last years and tried to establish institutionalised civilian authority over the PLA. To this end, Deng dismissed the Yang brothers, despite the fact they were his closest personal friends, largely because they represented a group of politically ambitious officers that could potentially form a second power centre vis-à-vis Jiang Zemin, chairman of the CMC (the Central Military Commission). In this way, Deng placed national interests above his personal feelings-a great historical service to long-term stability in the PRC. More importantly, he tried to enhance the institutional authority of the CMC chair in the hands of a civilian leader. First, he retained for his successor all the institutional powers he held. Among these is the power of final veto over personnel appointments and ultimate control of the nuclear button. Second, he promoted a number of professionally-minded generals to key posts in the military. These generals had no political ambition and were not interested in ideological dispute. Third, Deng endorsed the CMC's new idea of shifting the PLA's national defence strategy from his own notion of 'fighting a people's war under modern conditions' to 'fighting a regional war under high-tech conditions', a move which helped unify the strategic thinking of the whole PLA. ${ }^{7}$

In the meantime, Jiang, with Deng's backing, strengthened the management process over the PLA. The most important measure in this regard was to establish clearer lines of power and responsibility with the chair of the CMC as commander-in-chief. The decisions that the chair can make personally and what he has to discuss in the meetings of the CMC and in the meetings of the Politburo Standing Committee are now defined clearly. Meetings of this standing committee are important in that the guiding principle of decisionmaking there is collective leadership. This institutionalises civilian authority over the generals and prevents 
another strongman emerging to take over the military. Clear provisions are now in place which establish how policy powers are divided between the military and civilian leaderships. ${ }^{8}$

Progress in institutionalising civil-military relations in the postDeng era can be attributed to the efforts of both Party and PLA leaders to establish regulations governing the bilateral interactions. First, regulations have been introduced to prevent civilian and military leaders from involving themselves in areas outside their responsibilities - a phenomenon which, in the past, has been the catalyst for the formation of party factions and political-military alliances. In the last decade, there have been no signs of party leaders trying to infiltrate and influence the military with their own power manoeuvring, and vice-versa. As the military is effectively insulated from civilian politics, the PLA high command is able to maintain a high level of autonomy. As a result, unity in the military leadership has reached a level unseen since the late 1950s.

Second, both Party and military leaders cooperate to prevent general intra-party policy debate escalating into factional strife. A series of codes of conduct have been implemented for consensus building, including extensive consultation, debate in Party/PLA fora and decisionmaking that takes all affected interests into consideration. Efforts are made to limit the scope for disputes between civilian and military leaders to intensify and get out of control. Specifically, there is stricter division of power in relation to policy formulation regarding civil and military matters. Basically, PLA leaders distance themselves from interfering with non-military decisions and civilian leaders are forbidden from interfering in military administration. On issues of national security, the Politburo, with the participation of top PLA commanders, is the locus of decisionmaking power. In addition, stronger channels of communication have been developed between relevant government departments in the fields of foreign affairs and defence. Various inter-departmental leadership groups composed of both civilian and military leaders have been set up to coordinate China's international pursuits.? 


\section{The changing role of the military in Chinese politics}

As pointed out by Harry Harding, the military's role in national politics has been characterised by an intriguing paradox. On the one hand, the PLA possesses an impressive array of resources with which to influence national policy. On the other hand, the PLA has never seriously challenged the civilian leadership on any major policies, even on those related to national defence. ${ }^{10}$ On the contrary, it has been ordered to do things which are in direct conflict with its own interests. One typical example was the Party's deliberate policy to reduce the military budget throughout the 1980s. Deng asked the military to exercise patience with, and tolerance to, this policy even though it gravely undermined the PLA's modernisation efforts. "Similarly, the PLA was ordered to give up the bulk of its industrial and commercial interests in 1998. This eliminated a substantial proportion of the PLA's extra-budgetary income, adversely affecting the living standards of a large number of service men and women. Generally speaking, the civilian authorities have maintained an impressive balance between providing the PLA a privileged position in the country's governing process and placing constraints on the PLA's exercise of political influence.

Three factors may offer an explanation of this paradox. The first is historical, but may no longer be valid. ${ }^{12}$ For a long time the PLA was fragmented because it was made up of a number of relatively independent field armies. This prevented it from developing a complete corporate identity. Civilian leaders also often adopted a divide and rule strategy, pitting one group of senior officers against another in Party politics. Therefore, individual generals from different service origins were constantly involved in the Party power struggles. ${ }^{13}$ Without a concerted voice in talking to civilian leaders, the potential influence of the PLA was greatly curtailed

The second factor limiting the PLA's political influence is institutional. The ultimate sign of the Party's effective control over the military is the appointment of a civilian as commander-in-chief. 
The military may have some influence over the choice of candidate but does not have veto power over this vital issue. From the outset, the Party established a complete set of controlling institutions within the military-the network of party committees and political departments which are charged with missions of personnel management, discipline reinforcement, ideological indoctrination, internal security, welfare and recreational activities. Party functionaries are active officers with military rank equal to the commanders. This is the foundation of the "double commanderin-chief system' (shuangzhangzhi) in the PLA.This web of institutional controls has been quite effective, providing a means for Party leaders to interfere in PLA affairs.

The third factor is cultural. Throughout Chinese history, civilian control over the military has been the rule, while military intervention has always been strongly denounced.Although military involvement in politics has occurred from time to time, this was mostly when the central government was on the verge of collapse or when no effective civilian government existed at all. Since ancient times, the military has always been subject to a powerful cultural pressure to obey orders from the civilian leadership, particularly the emperors. ${ }^{14}$ In the nineteenth century, the army took advantage of national chaos to become the most powerful institution in China.As peace and stability gradually returned and China embarked on a path of deradicalisation in the late 1970s, this cultural tradition of civilian supremacy over soldiers was restored. This is one of the reasons why Jiang Zemin, a civilian with no military experience whatsoever, has been able to command the PLA with relative ease.

Despite all these constraints, the PLA is still the dominant political institution in the PRC. And it pursues its political and corporate interest powerfully. It draws its strength and influence from many sources. First, it is a large and disciplined organisation that controls lethal weapons. Its internal structure is far more cohesive than that of any other political and social organisation in the country. As in other countries, the numerical, organisational, economic, and coercive weight of the military easily makes it a force nobody can safely ignore. ${ }^{15}$ 


\section{The formulation of chinese defence and forelgn policy}

The second source of PLA power is its legitimacy among the majority of the population. The PLA was long viewed by the population as the best army China had ever seen. It helped restore order in the country after over a century of chaos. It lifted China's international status as a great power by fighting to a stalemate with the United States in Korea. It actively participated in the domestic economic construction and has contributed to natural disaster relief at a scale no other social organisation could hope to match. Mao's call to 'learn from the PLA' was genuinely answered by the people in the 1960s.

The Cultural Revolution gravely tarnished the PLA's image, when it was involved in Party factional infighting and was used as an instrument of class struggle. The PLA worked hard to repair the damage during the Deng era but suffered another major setback in 1989. For a while, the notion that the PLA was a people's army seemed far from reality.

After more than a decade, however, the PLA's public image and standing has reached a new high. During the 1990s, the PLA was involved in numerous disaster relief efforts. Its fight against the massive flooding across the country in 1998 moved many TV viewers, as they saw over one hundred PLA generals and more than 500,000 soldiers working on the river banks day and night to save the lives of a large number of ordinary people. Certainly the population resent the level of corruption amongst PLA personnel and the privileges attached to the organisation. On balance, the PLA is still respected, especially in rural areas. It is regarded as indispensable for maintaining social order. This public support gives the PLA an advantage in its interactions with other political institutions in China.

The third source of PLA power is institutional and rests on the politically independent status of the CMC. The CMC wields power with a high level of autonomy. Officially, it occupies the same level in the Party hierarchy as the State Council and the Standing Committee of the National People's Congress. Theoretically, it is under the Politburo in the hierarchy, but in reality it largely operates outside the Politburo's reach. This is because Mao 


\section{Power and Responsibility in Chinese Foreign Policy}

deliberately separated the government and military systems under the formula of 'zhengzhijiu yi zheng, junwei yi jun'-the Politburo's realm is state affairs and the CMC's is military affairs. Deng inherited this tradition. The $\mathrm{CMC}$ reported its affairs only to him throughout the 1980s. Following his two predecessors, Jiang has made efforts to prevent his Politburo colleagues from becoming involved in CMC affairs. The CMC has created its own autonomous power centre and enjoys the final say on many things ranging from personnel to legal, commercial and cultural matters. Reflecting the notion that political power comes from the barrel of a gun, whoever controls the CMC becomes the ultimate ruler of the nation. Jiang's rise in the Party is due largely to the fact that he has been accepted by the PLA as undisputed chair of the CMC. As a result, the Party and the PLA are jointly coordinated under jiang as party boss and commander-in-chief.

These changes show the PLA transforming gradually from a revolutionary army driven by ideological ferment to a professional, increasingly depoliticised military, conscious more of the national security issues and inclined less to get involved in intra-party factional activities. The PLA has acquired a cohesive corporate identity. Its corporate interest is best protected when there are no destructive outside intrusions. As the symbiotic relationship weakens, the PLA's new identity will affect its relations with the Party. This can be further seen from an analysis of the PLA's efforts at professionalisation.

\section{Rising professionalism and corporate identity}

The PLA has been a professional military all along, even though it has taken many other missions regarded as non-military by Western standards. It is unlikely that a non-professional military could fight to a stalemate with the powerful US army as the PLA did in the Korean War. The PLA has long been called a revolutionary professional army, similar to the nature of the Israeli armed forces. In the last two decades, however, the Chinese military has lost its revolutionary nature but is increasingly showing signs of becoming a fully professional organisation. 


\section{The changing ideological foundation of civil-military relations}

One major aspect of CCP-PLA relations before the Dengist reforms was the strong ideological current in the armed forces. Ideological control was an integral part of Party control over the PLA. Therefore, the PLA became class-based and an ideological model for the rest of society. Since the 1980s, the ideological foundation of the PRC has gradually shifted towards nationalism. ${ }^{16}$ This has had a profound impact on civil-military relations. First, ideology is seen as being too abstract to serve as a basis for the modernisation efforts of the PLA-an ideologically inclined military would reject professionalism as a primary goal of the armed forces. Second, it is easier for the Party and the PLA to find common ground in nationalism, specifically defined as national sovereignty, national reunification, territorial integrity, vital economic interests and national prestige in world affairs. As the PLA is no longer required to serve the narrow purposes of the working class, it is able to embrace a wider definition of national interests, and is thus more readily accepted by the population, which has been growing increasingly cynical about communist ideology. Third, as Party-military relations are guided by common national goals rather than ideological correctness, there is less need for the Party to indoctrinate the soldiers forcefully-soldiers pick up patriotism themselves. Bilateral relations consequently become easier to maintain.

\section{Setting up new strategic national defence guidelines}

One key measure of a professional military is its defence strategy. Since 1949, the PLA has altered its defence strategy several times, shifting from following Mao's people's war doctrine to adoption of Revolution in Military Affairs (RMA) as the guide for modernisation. With this evolutionary process the PLA has gradually shifted from being a tool of revolution required by the people's war principle to the guardian of national security with an emphasis on external missions. Indeed, the RMA type of war cannot be targeted against domestic enemies. The PLA's adoption of RMA 
has provided a timely guideline for improvements in its national defence strategy, both in theory and in practice. PLA generals are now trying to translate the RMA concepts into their professional war preparation-they are now more convinced than ever that winning a hi-tech war requires hardware superiority, sound tactics, and a suitable force structure. In 1993, the CMC put forward a new national defence strategy as a guide for modernisation of the PLA.The current campaign of disseminating RMA ideas within the Chinese military will further improve this strategy and address its doctrinal defects. ${ }^{17}$ First, the new strategy stresses the necessity of forward defence, recognising that in a high-tech war the enemy can launch precision strikes from long distance. ${ }^{18}$ While expanding defence depth may not stop long-range attacks, if the enemy can be effectively engaged in the outer defence line, the PLA may at least inflict greater human losses on the enemy and secure precious early warning for further defensive mobilisation.

Second, the high-tech strategy is largely an offensive oriented strategy, reflecting the shift in emphasis from the 'defensive' towards the 'active' side of war preparation. Following the Gulf War, the PLA quickly realised that high-tech wars will not be fought along fixed defence lines. Trench warfare will rarely occur. Accordingly, China's military approach has changed from yifang weizhu fangfan jiehe, or 'defence as overall posture, offence as the supplement', to linghuo fanying gong fang jiehe, or 'adroit response based on a combination of offensive and defensive capabilities'. Technological innovation has increasingly blurred the boundaries between offensive and defensive weaponry. Digital battlefield, electronic soft kill, and pinpoint elimination of the enemy's key targets all indicate that it is the offensive side that can seize the first initiative of the war and has the best chance of success. The offensive posture and pre-emptive strike are especially crucial for a weak military at the beginning of a high-tech war. ${ }^{19}$

Third, the strategy is forward-leaning. Its high-tech focus aims mainly at defence against strategic concerns, namely the major military powers. At the same time, the strategy is flexible in principle, catering to different scenarios, from major wars to small- 
scale border conflicts. This is the PLA's response to China's changing security environment in the post Cold War era. The new strategy is also forward-looking, geared to preparation for action in the new century. It prescribes concrete measures for weapons programs, force organisation, campaign tactics, and research priorities, which are not aimed at equipping the PLA in the next few years but at the frontiers of hi-tech breakthroughs some decades from now. ${ }^{20}$

What is the significance of this new military thinking to the professionalisation of the PLA? Simply put, it has set a proper direction for development. Without a sound strategic theoretical framework, even if the PLA acquired sophisticated weaponry in the new century, this weaponry could not be used to its full potential. ${ }^{21}$ Proper guidelines, high-tech weaponry, and a foresighted vision for development form the basis of a much more open and pragmatic PLA.

\section{Creating an élite officer corps}

No more than ten people remain in the military leadership who joined the Party before the founding of the PRC.And they will all depart the scene in less than three years. Soon the revolutionary tradition will disappear from the PLA. This will certainly facilitate professionalisation. Already the majority of top office holders are highly-educated technocrats without personal experience in revolution. They are imbued with common sense and scientific knowledge, but they lack the spirit of radicalism that characterised earlier military leaders in China. The result is that they are less likely to form factions among themselves along political and ideological lines. This new tendency can be seen more clearly at the lower levels in the PLA. Now 600,000 officers ( 90 per cent of the whole officer corps) have higher education qualifications, 20,000 officers have a Masters degree and over 4,000 officers have doctoral degrees. This new organisational make-up marks a clear break from the PLA's earlier tendencies. ${ }^{22}$ Sooner rather than later the PLA will become further depoliticised and dem ideologised. 
The fundamental change has gone much deeper than the organisational make-up of the officer corps. There are many other signs of professionalisation resulting from the change of guard. The PLA high command has substantially reformed military training and education. Officers have to go through an extended period of re-learning to meet the new requirements of fighting wars in the new era. Now, all military officers have to study new technologies, handle computers and get familiar with the targeted enemy forces. Promotion is closely tied to their study efforts. One of the assessment criteria is the extent and quality of their published material in both academic journals and internal policy debate. For instance, to be promoted into senior posts each officer must undertake a period of intensive study in the 'advanced class of generals' in the PLA National Defence University. ${ }^{23}$ It is said that the CMC chairman and vice-chairmen all read the students' graduation theses. In this way they are able to identify talented successors from this class.

Wang Zhuxun's promotion serves as a telling example of the emerging élite nature of the PLA officers corps. He was commander-in-chief of the 14th Group Army when he joined the class for generals in the early 1990s. He wrote a graduation thesis entitled The Strategic Path of Yunnan, which argued that if there were a war on China's coast, China's strategic path through the Pacific would be blocked. This would seriously affect China's economy because more than two-thirds of China's exports and imports follow this route. Then he suggested that China should prepare an alternative strategic path that would, according to his opinion, run from Yunnan through Burma to the Indian Ocean. His thesis caught the attention of General Zhan Zhen, the third most senior military leader in China, who passed it onto Jiang Zemin. Jiang also praised the thesis highly, claiming that Wang Zhuxun was exactly the kind of person needed for the military modernisation, a person who had broad strategic vision. Wang was later promoted to the post of commander-in-chief of military region. More generally, almost all the current top office holders have an impressive list of publications. This has lifted the PLA's level of professionalism. 


\section{Wars and responsibilities}

How does China's international behaviour fulfil its responsibilities as a major world power? This is a tricky question. People can hold different interpretations of what is responsible. One nation can perceive its behaviour on the world stage to be quite reasonable but other states may think just the opposite. Despite the increased strength of liberalism and the democratic peace thesis in the post Cold War era, the world is in reality still dominated by nationstates pursuing national interest above everything else. The best example of this is the US efforts to build NMD regardless of the opinions of the world community, including western countries.

\section{Serving national interests as the top mission}

In the history of the PRC, the PLA has been involved in nine wars and armed conflicts. These can be roughly divided into two groups - wars fought for ideological reasons and wars fought for the protection of national sovereignty and territorial integrity. The first group includes the Korean War with the United States in the 1950s, the Vietnam War in the 1960s, the Sino-Soviet border conflict in 1969, the Sino-Vietnamese War in 1979 and the SinoVietnamese border clash in the first half of the 1980s. The second group is comprised of the Sino-Indian Border War in 1962, extension of the civil war with the Guomindang (GMD) in the 1950s and 1960s, the suppression of the Tibetan Revolt in 1959 , the recovery of Xisha Island in 1974, and the maritime clash with Vietnam in 1988. Some cases in the second category were not without ideological motivation.

The number of wars that China initiated or was forced to launch has been declining. Most of the actions were taken in the 1950s and 1960s, and no war involving China took place in the 1990s. This downward trend has underscored two important facts. First, after China gave up treating other nations with any ideological prejudice, the reason for war was significantly reduced. Second, even though China has always adopted a non-negotiable approach towards sovereignty and territorial issues, it realised in the 1980s that as a responsible international player it should always place peaceful settlement of disputes above military threat. ${ }^{24}$ Professor 
lain Johnston of Harvard University found that China's involvement in militarised disputes diminished over the period 1949-92 and found that this correlated with a reduction in border controversies and an increased sense of status internationally. And this was correlated with China's greater economic interdependence with the world economic system. ${ }^{25}$

This fundamental change has been behind the abandonment of Mao's slogan of 'liberating' Taiwan in 1979. Deng's proposal to settle Hong Kong and Taiwan problems with a formula of 'one country, two systems' was the best offer China could make for a matter concerning national sovereignty. At the same time, China also proposed to other countries that territorial disputes should be resolved through dialogue and mutually acceptable terms. Under this guideline, China has successfully reached border agreements with Russia, Mongolia, Central Asian countries, Burma, Pakistan and Vietnam. Its land border negotiation with India is progressing well at this moment. All this has shown that China sincerely holds the principle of peaceful reunification of the lost territories. Indeed, China has made more concessions than its counterparts in all these negotiations. Contrary to the claim that China has an expansionist agenda, we can see that the Chinese map is smaller now than at any time in the last century.And its presence in the South China Sea is the smallest among all the claimants. ${ }^{26}$

Removing the ideological basis for war and emphasising peaceful settlement of territorial disputes represented major progress toward China becoming a responsible member of the international community. This is derived from China's overriding national goal of economic development. Objectively speaking, the PLA has never been opposed to dropping military threat as the foundation of foreign and defence policy. It was the primary victim in various wars fought along these lines. It paid a heavy price in achieving a stalemate with the United States in the Korean War and it almost suffered a nuclear surgical strike from the USSR in the 1969. China's peace-centred foreign initiative in the post-Mao era has given the PLA an opportunity to tackle its major problem-backward 
equipment. As a professional army and a key component of the Party-state, however, the PLA has never wavered in carrying out orders of war from the civilian leadership. As a tool of revolution in the past it viewed the United States as an imperialist power and the USSR as a revisionist enemy. In settling territorial disputes, it crossed the border to attack several of its neighbours. In the absence of revolutionary zeal, the PLA will have to forge a new identity and a new mission. If this new role is to serve as guardian of national interests, to what extent will this affect its external behaviour? Does this role promote modernisation efforts? These are crucial questions that may cause disagreement between the civilian and military leaders. So far there has not been any major conflict but tension is always beneath the surface, since an economics-in-command political line may delay many key arms upgrading programs, owing to the relatively low priority allocated to developing the military.

It is necessary to define how PLA generals see the concept of national interests. First, the PLA's role in the national interest is to secure the PRC from the external threat. Second, national interests entail efforts to guarantee the integrity of national territories, including efforts to recover territories lost due to China's historical weakness. Although it is very unlikely that China will be invaded, it suffers constant intimidation from Western powers - the 1989 sanctions, the forced inspection of the Yin $\mathrm{He}$ shipment, the de facto containment and the continuing Cold War mentality of 'peaceful evolution'. The interventionist tendency in international relations worries the PLA and this has made its responsibility to recover lost territories an even heavier burden to shoulder. China does have human rights problems and ethnic conflicts at home-separatist movements are active in Tibet and Xinjiang and receive international support. Taiwan's ongoing drift away from the mainland poses an immediate challenge to the PLA. All this has convinced the PLA that it is living in a hostile world, ${ }^{27}$ and the cruel truth is that it is far from being ready to face the challenge. 


\section{The war or peace discourse}

The reduced involvement of the PLA in the country's domestic politics has, as mentioned earlier, reduced the scope for disagreements between the civilian and military leaders over internal policy. This is especially true in the economic field. The PLA does not have any serious disagreement with the marketoriented reforms, although it believes that they have created new challenges to the maintenance of its corporate cohesion. ${ }^{28}$ In terms of politics, the PLA probably supported Jiang's surprisingly hardline response to Falun Gong in 1999-another example of Party and military sharing vital interests in the monopoly of power. In terms of military policies, the PLA has had a high level of autonomy in military administration and Party interference has been minimal since the early 1990s. The Party sometimes denies specific military demands for weapons development, such as when it vetoed the PLA's request to build an aircraft carrier. On the whole, however, the CCP tries to meet the military's hardware upgrading needs. It does this partly because it recognises that continued relations are founded on give and take, but also because a powerful army helps the Party consolidate its power.

In the area of foreign and defence policy, however, discord is discernible between the two, mostly related to how to respond to events in Sino-US and cross-Strait relations. The mainstream civilian leadership is now composed of Jiang Zemin and Zhu Rongji, both of whom are more pro-West than their predecessors and possibly even their successors. They were trained in the Westernstyle universities in the 1940s. Although strong nationalism propelled them to join the revolution then, they all had an unfulfilled dream of studying in the United States. And their world outlook is wider than those who will form the core of the fourth generation leadership which received communist education in the 1950 s and 1960s. They know that China now has its best chance in many centuries to become economically rich and militarily powerful. The military threat to China is minimal, except for foreign 
involvement in the Taiwan Strait. The world situation is mostly peaceful and will remain so for a long time. The domestic situation is fairly stable, thanks to both political restrictions and economic growth. So China's security should be enhanced through promoting world peace. ${ }^{29}$ The only thing that could hinder the rise of China is war with Taiwan.

This is the reason why the civilian leaders have decided that China's foreign policy in the post-Cold War era should be nonconfrontational towards the West. The bottom line of this policy guideline is to handle the Western challenge cleverly in order to create a stable international environment for China's economic take-off.This is the key principle Deng laid down for his successors. ${ }^{30}$ Following this principle, Jiang always takes a long-term perspective in handling acute conflicts with the West. Even if the quarrels involve matters of Chinese sovereignty-for example, US arms sales to Taiwan-Jiang tries to leave room for compromise later for the sake of maintaining at least a workable economic relationship. The exception to this was China's policy towards NATO's Kosovo war. ${ }^{31}$

At times this may present a problem for the military. But the PLA has so far not challenged jiang's soft foreign policy tone. As mentioned earlier, the PLA has become increasingly externallyoriented and non-interventionist towards intra-party politics. This makes the job of the civilian control over the armed forces a lot easier for the post-Deng leaders, quite contrary to many analysts' predictions. No one dismisses the fact that the PLA still wields enormous political influence, especially at times of succession. Yet the PLA chooses to use that influence prudently and selectively. On the whole, its weight has been most clearly felt in areas of foreign and defence policies. This is a key political role played by the PLA, but it does not fall outside range of activities considered legitimate by western countries.

The PLA has for some time been prevented from taking tough attitudes towards international politics. It tolerated the suppression of its budget increase for a decade in the 1980s. Reacting to the 
civilian request, the military pledged not to use force to resolve the South China Sea dispute in 1993 when other claimants continued to occupy islets in dispute. It voiced its support for Jiang's peace initiative towards Taiwan, embodied in his pronouncement that 'Chinese do not fight Chinese' in 1995, despite its full awareness that the move would not work. When its program of upgrading land and sea-based long-range nuclear missiles was at a crucial stage of development, the PLA accepted the civilian leaders' 1997 decision that China should stop nuclear tests. Moreover, it let go of its vast economic and commercial machine in 1998 at the order of the Party. Of course all this was not done without a level of disgruntlement on the part of the PLA. Yet, the fact that the PLA has accepted what was imposed upon it indicates that it is conscious of the international trend towards peace and is trying to adapt to the new circumstances. Another major factor is the current transitional difficulties in the PLA's weapons R \& D. Large numbers of new high-tech weapons designs have just passed the laboratory test and it will take many more years for them to become deployable. The top commanders know that this is not time to take action and are taking advantage of the West's engagement strategy toward China to further the country's defence modernisation. ${ }^{32}$

The post-Deng civilian leadership does not disagree with the PLA's perception of external threat to China's national interests. Discord arises in deciding how to handle the threat. This concerns the timing for a major counter-offensive, its intensity, and the way of retreating from a clash. Generally speaking, the military would like to see a hardline reaction to challenges to China's sovereignty, including the threat of military force. In contrast, the civilian leadership would have more to consider in a crisis-the economic consequences, international outcry, and the long-term effects on national interests. This discord is still more technical than fundamental at this stage. Civilian leaders have been successful in convincing PLA generals that if the Chinese military is not ready for a major action, it is in the PLA's best interests not to be dragged into a war prematurely. The question is how long the PLA will continue to accept this argument if it does not receive a firm 
commitment from civilian leaders to address the problem of military backwardness. The debate between a soft vs. hardline response to Western threat may escalate to the point where the overall direction of national development is altered. Recent world events, such as the enhanced US-Japan military alliance, Lee Tenghui's 'two-state' thesis, NATO's bombing of the Chinese embassy in Belgrade, and Chen Shuibian's election victory in Taiwan, have placed the civilian and military leadership at a crossroads.

The PLA will not always take whatever is imposed upon it by civilian leaders at any cost. As guardian of national interests it will have to raise its voice when it believes the civilian leadership has compromised too much. This is most vividly reflected in the PLA's attitudes towards Taiwan. The PLA missile launches in 1995-96 carried a clear message for the Taiwanese leadership: do not force our hand. Yet at the time, Jiang was still under illusions that the two sides could work out something peacefully.After Lee Tenghui's US visit in May 1995, Jiang was under pressure from PLA generals and state security personnel to revise the 'one centre, two basicpoints' guiding principle set by Deng for China's modernisation. The military sought to add to Deng's 'one centre' (the economics in command) another centre, namely safeguarding national sovereignty and territorial integrity, which may mean a major military build-up. Indeed, Deng once told PLA leaders that the PLA should see protection of national sovereignty and territorial integrity as the state's primary task..$^{33}$ This provided PLA generals with a powerful weapon to demand a high level of preparedness.

The Politburo's Beidaihe conference in August 1995 put an end to the debate, for a while, and upheld Deng's non-confrontational diplomatic principle, after Jiang persuaded the participants that it was not time to confront the West. ${ }^{34}$ The same Beidaihe conference in 1999, however, came to the new conclusion that NATO's bombing of the Chinese embassy exposed the bottom line of the West's policy toward China. Choice between peace and war was no longer in Beijing's hands. The civilian leaders, as pointed out by senior PLA officers, decided in a timely and resolute manner to enhance the intensity of military modernisation. The Party centre promised that the PLA would acquire the capacity 
to win a high-tech war with a major military power as quickly as possible. Obviously this would require a substantial increase in the national defence budget. Although promoting economic development is still the Party's central task, the civilian leaders' position in handling the contradiction between economic construction and military modernisation has tilted toward what the PLA has argued for all along. ${ }^{35}$ The consequences of such a policy direction are profound. The Chinese leaders have now dropped Deng's assertion that major wars could be avoided. Their current assessment of the world order has been most pessimistic since the beginning of the 1980s. The bombing of the Chinese embassy has imposed great urgency on China's defence modernisation. In late 1999, Jiang issued orders on behalf of the Politburo to the participants of the PLA chief-of-staff conference that the PLA should accelerate military readiness for war. ${ }^{36}$ While economics is still in command, more national resources will be devoted to military build-up. ${ }^{37}$

Yet it is interesting to note that, despite his supportive remarks on a quickened military build-up, Jiang has been reluctant to move China in a direction that can be interpreted as militarist.Whenever there are major international events damaging China's national interests he stresses the hard side of the policy. Whenever the tension eases, however, he retreats from his commitment to immediate war preparation. The same is true of Zhu Rongji. His tough talk in the April 2000 news conference, in which he addressed the question of Taiwan's presidential election, should be seen in the same light. Taiwan is a likely area where China's civilian and military leadership may differ in their policy emphasis for a long time to come.

\section{Conclusion}

There has been a change in relations between the Party and the PLA in China. The passing of the first and second generation party and military leaders has reduced the scope of the intervention of the military in domestic politics. The PLA is increasingly presenting itself as a separate identity with distinctive corporate spirit and interests. Professionalism, as embodied in the slogan of winning 
the next major high-tech war, has been set as the ultimate goal for military modernisation. All this has made it possible for the PLA to transform itself from the tool of revolution to the guardian of national security. On the other hand, the PLA has no quarrel with the Party's command over the gun. Party control is seen as legitimate because the Party is the founder of the PLA in the first place. More importantly, the military sees benefits in protecting the Party, with which it shares vital vested interests. This has given rise to a relationship of give and take. If we observe this relationship in the longer term, however, we may see cracks in the relationship. As a highly professionalised organisation, the military will very likely outlive the CCP as a political party in power, which may either collapse if it cannot curtail its internal decay due to corruption or lose office to another new political party if fundamental political reform is introduced. Therefore the current Party-military relationship is undergoing transitory change, although this period of transition will necessarily be long.

The interaction between the military and the Party's third generation leadership is particularly indicative of the shared ties of give and take. In the last decade the military finally rid itself of the strongmen's personal control. As a result it has achieved a much higher level of autonomy. This is actually the most important reason for the PLA to accept Jiang Zemin, a political player who has never posed any threat to the PLA's vital interests. As far as civilian leaders are concerned, they will have to rely more on institutional power rather than personal authority to influence the military. The rules of the game are clearer than before. As a result relations between the Party and the PLA are easier to manage, but in the long run of time this trend will facilitate the divorce between the Party and the military in the form of a depoliticised and state-run military.

This progress does not preclude the possibility of the military taking hardline attitudes towards matters of national security. The efforts of professionalisation may focus the eyes of officers and men away from domestic concerns. The top mission of securing national interests may cause the PLA's external functions to be perceived as aggressive. Especially when the PLA is eager to fight 
for national territorial integrity, it may be viewed as sabre rattling. This is exactly the case with the Taiwan problem. The PLA will not initiate any action across the Strait without a reason because this does not serve the interests of China and the PLA. Particularly with the question of Taiwan, the choice between peace and war is no longer in the hands of the CCP leadership. Here the PLA may differ with its civilian commanders over an estimate of the geostrategic situation. Both of them may agree that more efforts must be made to empower the military and both of them may even agree that war may be inevitable, but, whereas the civilian leadership sees the possibility of prolonging the peace and the benefits of placing economic ahead of military needs, the military calculates its capability according to a worst case scenario and thus demands more inputs. So far there has not been a serious rift but that situation could easily change in a crisis. Eventually the civilian leadership will have to go along with the military, probably with the fourth generation of the Party core, because it dares not carry the blame of betraying national interests. We may see a Chinese military that will in the future become more assertive in assuming external missions.

\section{Notes}

1 See for instance, Samuel Huntington, Soldiers and the State, (Belknap: Harvard Massachusetts, 1957).

2 Samuel Finer, The Man on Horseback: the role of the military in politics (Westview: Boulder, 1988).

3 There is a large body of literature on China's civil-military relations, although the bulk of it has become obsolete. See Jeremy Paltiel, 'PLA allegiance on parade: civil-military relations in transition', China Quarterly, no. 143, (September 1995); David Shambaugh, 'China's post-Deng military leadership', in James Lilly and David Shambaugh (eds), China's Military Faces the Future (M.E. Sharpe: Boulder, 1999).

4 Ellis Joffe first raised this issue of 'a separate army' in his 1993 article, 'The PLA and the Succession Question', in Richard Yang (ed.), China's Military: the PLA in 1992//993 (Taipei: Chinese Council of Advanced Policy Studies, 1993), 150. 


\section{The formulation of Chinese defence and forelgn policy}

5 See various chapters in Roderick MacFarquhar (ed.), The Politics of China: the eras of Mao and Deng (Cambridge: Cambridge University Press, 1997).

6 For more on this see You Ji, 'jiang Zemin: struggle for the post-Deng supremacy', in Maurice Brosseau, Suzanne Pepper \& Tsang Shu-ki (eds), China Review 1996 (Hong Kong: The Chinese University of Hong Kong Press, 1996), pp. 1-28.

7 For a more detailed analysis, see You Ji,. The Armed Forces of China (Sydney, London \& New York: Allen \& Unwin and I.B. Tauris, 1999), 28-55.

8 Liu Yicang and $\mathrm{Ku}$ Guisheng, You zhong guo tese de guofang jianshe lilun [The national defence theory of the Chinese characteristics] (Beifing: the PLA Academy of Military Science Press, 1993), 216.

9 See Michael Swaine, The Role of the Chinese Military in National Security Policymaking (Santa Monica: RAND, 1996).

10 Harry Harding, 'The PLA as a political interest group', in Victor Falkenheim (ed.), Chinese Politics from Mao to Deng (New York: Paragon House, 1987), 213-14.

11 For a detailed analysis of the budget cut, see Shaoguang Wang, 'Estimating China's defence expenditure: some evidence from Chinese sources', The China Quarterly, no. 147 (September 1996); and, for its political consequences, see You Ji and lan Wilson, 'Leadership by 'lines': China's unresolved succession', Problems of Communism, Vol. 39, no.l (January 1990), 28-44.

12 Michael Swaine elaborated the historical origin of the politicalmilitary factions in his book, The Military \& Political Succession in China (Santa Monica: RAND, 1992).

13 Harding, 'PLA as a political interest group'.

14 On this cultural tradition, Ray Huang wrote an excellent chapter in his book, 1587: a year of no significance (New Haven: Yale University Press, 1981).

15 Harding, 'PLA as a political interest group'.

16 See for instance, Yongnian Zheng, Discovering Chinese Nationalism in China (London: Cambridge University Press, 1998).

17 For a more detailed analysis of the PLA and RMA, see You Ji,'Revolution in Military Affairs and the evolution of China's strategic thinking', Contemporary Southeast Asia, 21, no. 3 (December 1999), 325-45.

18 Guo Yongjun, 'Fangkong zuozhan ying shuli quanquyu zhengti fangkong de sixian' [Air defence should be guided by the theory of area and integrated defence], Junshi xueshu, no. II (1995), 47-49. 


\section{Power and Responsibility in Chinese Foreign Policy}

19 Shi Zhigang, 'Jiji fangyu zhanlue sixiang zai xinshiqi junshi douzheng de tixian' [The application of active defence strategy in the military preparation in the new era], The Journal of PLA National Defence University, (August-September 1998), 100.

20 Tao Bojun, 'Dangde sandai lingdao jiti yu keji jianjun' [The Party's three generation leadership and strengthening the armed forces through technological breakthroughs], China Military Science, no. 3 (1997), 65-73.

21 Xie Dajun, 'Qiantan zhishi jingji jiqi dui junshi gemin de yingxiang yu tiaozhan' [The influence and challenge of knowledge economy to RMA], The Journal of PLA National Defence University, (January 1999), 27.

22 Wu Jianhua, 'Wojun zhonggaoji nianqing zhihui ganbu peiyang de kaocha yu jishi' [The review of promoting young senior officers in our army and its lessons], Journal of the PLA National Defence University, no. I (2000), 51.

23 This class admits students at the level of the army commanders. Each year about 50 promising young major generals are enrolled in the course.

24 Yao Yanjin and Liu jixian, Deng Xiaoping xinshiqi junshi lilun yanjiu, [Study of Deng Xiaoping's military theory in the new year] (Beijing: the PLA Academy of Military Science, 1994), 71-76.

25 Alastair lain Johnston, 'Cultural realism and strategy in Maoist China', in P. Katzenstein (ed.), The Culture of National Security (New York: Columbia University Press, 1996), 251-68.

26 The PRC's largest loss of territory took place in the early 1950s when Beijing essentially watched India occupy 900,000 square kilometres of Chinese territory, obviously due to political and diplomatic reasons. See Mao Zhengfa and Zeng Yan (eds), Bianfanglun [Theory of territorial defence] (Beijing: The PLA Academy of Military Science Press, 1996), 132-34.

27 Li Gang and Wang Qi, 'Zhengque renshi shijie geju duojihua qushi' [Correctly recognising the multipolarity trend in the world order], Journal of the PLA National Defence University, no. 9 (2000), 26-27.

28 Zhao Kemin, 'Dui xinshiqi wojun sixiang zhengzhi gongzuo shijian de huigu yu sikao' [The reassessment of and reflection on our army's ideological and political work in the new era], Journal of the PLA National Defence University, no. 10 (1999), 22-25.

29 Meng Xiangqing, 'Jiang Zemin de anquanguan chutan' [An initial study on Jiang Zemin's theory of security], Journal of Foreign Affairs College, no. 2 (1999), 38-42. 


\section{The formulation of Chinese defence and foreign policy}

Qu Xing, 'Shilun dongou jubian he suliang jieti hou de zhongguo duiwai zhengce' [China's foreign policy since the radical changes in Eastern Europe and the disintegration of the USSR], Journal of Foreign Affairs College, no. 4 (1994), 19-22.

31 I have made analyses of this exception in detail elsewhere, see You Ji, 'The China challenge in the new millennium', paper presented at the Strategic Update Conference, Parliament House, Canberra, 27 September 1999.

$32 \mathrm{Xu} \mathrm{Tao}$, 'Ruhe renshi woguo anquan liyi' [How to understand our country's security interest], Journal of the PLA National Defence University, no. I (2000), 16.

33 Peng Guangqian et al., Deng Xiaoping zhanlue sixianglun [On Deng Xiaoping's strategic thoughts] (Beijing: the PLA Academy of Military Science Press, 1994), 109.

34 See You Ji, "Changing leadership consensus: the domestic context of war games', in Suisheng Zhao (ed.), Making Sense of the Crisis Across the Taiwan Strait (London: Routledge, 1999), 77-98.

35 Peng Rixuan, Ying $\mathrm{Lin}$ and $\mathrm{Li}$ Tao, 'Zhongguo jundui xiandaihua jianshe huigu yu zhanwang' The review and forecast of the Chinese military modernisation], Journal of the PLA National Defence University, no. 5 (2000), 9.

36 Qian Guoliang, 'Quanmian luoshi silingbu jianshe gangyao gaobiaozhun zhuahao silingbu jiguan jianshe' [Comprehensively implementing the Guidelines for the Headquarters Construction], Journal of the PLA National Defence University, no. 6 (2000), 4.

37 Peng Rixuan et al., 'Zhongguo jundui', 9. 